\title{
KEKERASAN DALAM RUMAH TANGGA (ANALISIS FAKTA SOSIAL BERBASIS KONSELING FEMINIS TERHADAP KETIMPANGAN GENDER)
}

\author{
Suryanti
}

\begin{abstract}
Domestic violence (KDRT) is the most common violence of women in Indonesia. This occurs because of gender imbalances that differentiate women's and men's roles and rights in the community that places women in a lower status than men. The privilege of men as if they make women the property of men who are entitled to be treated arbitrarily, including by violence.The counseling theory approach that is considered relevant to domestic violence cases is feminist counseling. Concepts built in feminist theory use a system perspective, meaning that the process of counseling intervention is not only to individuals but the individual environment is given the treatment to ensure the solution of the root of the problem.The ability of counselors to empower individuals / communities within the victim's environment is a skill that must be sharpened by counselors who use feminist counseling. This theory is based on the principles of the personal is political, egalitarian relationship and the valuing perspective. The three concepts that become pillars of feminist counseling become an essential indicator in determining the ability of counselor in assisting women victims of domestic violence
\end{abstract}

\section{PENDAHALUAN}

Gender merupakan behavioral differences (perbedaan perilaku) antara laki-laki dan perempuan yang dikonstruksi secara sosial, yakni perbedaan yang bukan ketentuan Tuhan melainkan diciptakan oleh manusia (bukan kodrat) melalui proses sosial dan kultural yang panjang. Permasalahan gender di masyarakat sudah ada 
sejak manusia itu mulai muncul dimuka bumi ini. Namun pada awalnya ketika ilmu pengetahuan dan teknologi belum maju seperti saat ini, isu gender belum mendapat perhatian dan tidak dipermasalahkan baik oleh masyarakat secara umum maupun oleh kaum feminis. Hal ini disebabkan karena nilai-nilai budaya yang berkembang terkait dengan peran atau pembagian kerja, tanggung jawab serta citra baku laki-laki dan perempuan pada saat itu dianggap sebagai sesuatu yang wajar dan sah-sah saja seiring dengan perkembangan zaman yang diikuti oleh kemajuan ilmu pengetahuan dan teknologi informasi, perhatian masyarakat terutama kaum feminis terhadap fenomena sosial yang terkait dengan isu gender mulai menjadi fokus perhatian. ${ }^{1}$

Secara umum KDRT menurut UndangUndang (UU) No. 2 Tahun 2004 tentang penghapusan Kekerasan Dalam Rumah Tangga adalah setiap perbuatan terhadap seseorang teutama perempuan, yang berakibat timbulnya kesengsaraan atau penderitaan secara fisik, seksual, psikologis, dan atau penelantaran rumah tangga termasuk ancaman untuk melakukan pebuatan, pemaksaan, atau perampasan kemerdekaan secara melawan hokum dalam lingkup rumah tangga.2 UU ini memberikan informasi mengenai jenis-jenis tindakan yang digolongkan sebagai KDRT. Dari sisi perlindungan pada korban, UU tersebut merupakan salah satu kemenangan bagi atau hasil perjuangan dari berbagai kampanye mengenai KDRT menyusul meningkatnya jumlah kasus terkait KDRT di Indonesia.

Data tahunnan Indonesia dari Komnas Perlindungan Perempuan mencatat bahwa tindak kekerasan pada perempuan terutama kekerasan diranah domestic mengalami peningkatan setiap

\footnotetext{
${ }^{1}$ Ni Luh Arjan, Kesetaraan dan Keadilan Gender $(K K G)$ dan Tantangan Global,Vol. 1, No. 2 Agustus 2008, Jurnal Ekonomi dan Sosial, 1

${ }^{2}$ Pasal 1 butir 1, UU No. 23 Tahun 2004 mengenai Penghapusan Kekerasan Dalam Rumah Tangga.
} 
tahunya. Tahun 2010 tercatat kekerasan dalam rumah tangga berjumlah 101128 kasus, tahun 2011 sebanyak 113.878, jumlah ini mengalami peningkatan sebanyak 5,9\%. Sedangkan untuk tahun 2012 dengan jumlah 142.662 kasus juga mengalami penngkatan sebesar 11,61\% jika dibandingkan dengan kasus tahun sebelumnya. ${ }^{3}$ Kekerasan Dalam Rumah Tanngga (KDRT) dapat diposisikan sebagai akibat yang dilahirkan dari sebuah sistem sosial yang bias gender. Dalam prakteknya KDRT bisa terjadi pada semua lapisan masyarakat dari kelompok masyarakat kaya sampai miskin dari kelompok terdidik sampai yang tidak terdidik. KDRT bisa saja dilakukan oleh seseorang dengan penuh kesadaran bahwa apa yang ia lakukan adalah kekerasan, namun bisa saja pelaku menganggap perilaku kekerasanya merupakan bagian dari hak yang ia miliki yang dijustifikasi dengan otoritas yuridis ataupun dalil agama.4

Kekerasan Dalam Rumah Tangga (KDRT) yang dilakukan khususnya terhadap perempuan oleh pasanganya maupun anggota keluarga dekatnya, terkadang juga menjadi permasalahan yang tidak pernah diangkat ke permukaan. Meskipun kesadaran terhadap pengalaman kekerasan terhadap wanita berlangsung setiap saat, fenomena KDRT terhadap perempuan diidentikkan dengan sifat permasalahan ruang privat. Dari perspektif tersebut, kekerasan seperti terlihat sebagai suatu tanggung jawab pribadi dan perempuan diartikan sebagai orang yang bertanggung jawab baik untuk memperbaiki situasi yang sebenarnya didikte oleh norma-norma sosial atau mengembangkan metode yang dapat diteima dari penderitaan yang tak terlihat. Oleh karena itu pada kesempatan kali ini penulis akan memaparkan fakta sosial yang terjadi dimasyarakat

${ }^{3}$ Komisi Nasional Perlindungan Perempuan, Catahu Komisi Nasional Hak Asasi Manusia, Jakarta:Komnas Perempuan

${ }^{4}$ Abnan Pancasilawati, Kekerasan Dalam Rumah Tangga Perspektif UU NO 23 Thun 2004 tentang KDRT dan Hukum Islam, Vol 3 No 2 Juni 2003, Jurnal Equalita Stain Cirebon, 1 
terhadap ketimpangan gender terkait dengan kekerasan dalam rumah tangga dan solusinya dengan menggunakan konsep konseling feminis.

\section{PENGERTIAN KEKERASAN DALAM RUMAH TANGGA (KDRT)}

Kekerasan Dalam Rumah Tangga (KDRT) dapat diartikan sebagai tindakan kekerasan yang dilakukan oleh seorang pengasuh, orang tua, atau pasangan. Kekerasan secara terminologi dapat diartikan sebagai perihal yang bersifat keras atau perbuatan seseorang atau kelompok orang yang menyebabkan cidera atau matinya seseorang. ${ }^{5}$ Sedangkan kekerasan dalam Bahasa Inggris sebagimana dikatakan Elizabeth Kandel Englander yang dikutip oleh Rika Saraswati merupakan suatu bentuk tindakan yang dilakukan terhadap pihak lain, yang pelakunya perseorangan atau lebih, yang dapat mengakibatkan penderitaan bagi pihak lain.6

Berdasarkan situs terjadinya, kekerasan terhadap perempuan dapat dibedakan menjadi dua, yaitu kekerasan yang terjadi pada area domestic (KDRT) dan kekerasan pada arena publik. Pembedanya didasarkan atas unsur relasi sosial antara korban dan pelaku.

Menurut catatan Bank Dunia, bentuk kekerasan yang paling sering terjadi adalah kekerasan terhadap istri atau yang lebih tepat kekerasan terhadap perempuan menyebabkan dan melestarikan subordinasi. Subodinasi terhadap perempuan sudah berlangsung cukup lama dan bersifat universal, hanya untuk subordinasinya yang beragam dengan intensitas yang berbeda-beda. Subordinasi tidak sekedar perbedaan seksual dalam arti biologis, tetapi kemudian

\footnotetext{
${ }^{5}$ Pusat Pembinaan dan Pengembangan Bahasa Indonesia, Kamus Besar Bahasa Indonesia, (Jakarta: Balai Pustaka, 1994) 485.

${ }^{6}$ Rika Sararwati, Perempuan dan Penyelesaian Kekerasan dalam Rumah Tangga, (Bandung: PT. Citra Aditya Bakti, 2006), 13.
} 
berkembang pada perbedaan fungsi-fungsi reproduksi dan produksi, baik dalam penguasaan sumber-sumber ekonomi, idiologi kelas, maupun stratifikasi sosial melalui serangkaian sosialisasi untuk melanggengkan posisi perempuan yang subordinat. ${ }^{7}$

Kekerasan dalam rumah tangga, dalam prakteknya sulit diungkap karena beberapa sebab. Pertama, Kekerasan dalam rumah tangga terjadi dalam lingkup kehidupan rumah tangga yang dipahami sebagai urusan yang bersifat privasi, dimana orang lain tidak boleh ikut campur (intevensi). Kedua, pada umumnya korban (ister/anak) adalah pihak yang secara struktural lemah dan mempunyai ketergantungan khususnya secara ekonomi dengan pelaku (suami). Dalamaposisi ini, korban pada umumnya selalu mengambil sikap diam atau bahkan menutup-nutupitindak kekerasan tersebut, karena dengan membuka kasus kekerasan dalam rumah tangga ke publik berarti membuka aib keluarga. Ketiga, kurangnya pengetahuan dan kesadaan hukum masyarakat terhadap hak-hak hukum yang dimilikinya. Keempat, adanya stigma sosial bahwa kekerasan yang dilakukan oleh suami dipahami oleh masyarakat sebagai hal yang mungkin dianggap wajar dalam kerangka pendidikan yang dilakukan oleh pihak yang memang mempunyai otoritas untuk melakukanya. Pada posisi ini, korban sering enggan melaporkan kepada aparat penegak hukum karena khawatir justru akan dipersalahkan (blame the victim). ${ }^{8}$

Kekerasan dalam rumah tangga terjadi, karena masih adanya pemahaman yang keliru mengenai bias gender, dimana seorang perempuan harus tunduk kepada laki-laki, hal itu mengakibatkan

${ }^{7}$ Eki Nurhayati, "Domestik Violence", Jurnal, EQUALITA STAIN Cirebon, Vol No 2 Juni, 2003, 47-48

${ }^{8}$ Abnan Pancasilawati, Kekerasan Dalam Rumah Tangga Perspektif UU NO.23 Tahun 2004 tentang PKDRT dan Hukum Islam, Vol 3 No 2 Juni 2003, Jurnal Equalita Stain Cirebon, 95 
terjadinya kekerasan dalam rumah tangga. Bias gender juga menekan kaum perempuan untuk menjadi submisif dan menerima semua bentuk perilaku tidak adil yang lebih mengedepankan hak sosial atau orang lain daripada hak pribadi. ${ }^{9}$

Pasal 1 angka Undang-Undang Nomor 23 Tahun 2004 tentang Penghapusan Kekerasan Dalam Rumah Tangga. Tingginya laporan kasus kekerasan tersebut seperti fenomena puncak gunung es yang tampak di lautan, artinya bahwa angka kasus kekerasan dalam rumah tangga yang terungkap, dilaporkan hanyalah sedikit dibandingkan dengan kejadian senyatanya, jadi hanya menunjukkan puncak gunung es dari persoalan kekerasan terhadap perempuan dalam rumah tangga. Fenomena ini muncul karena perempuan korban kekerasan masih banyak yang enggan atau tidak dapat melaporkan kasus kekerasan yang menimpanya, akses untuk menyampaikan laporan, keberanian korban dan kepedulian masyarakat yang masih rendah, serta lembaga yang melayani juga merupakan faktor rendahnya laporan. Adapun terkait dengan bentukbentuk kekerasan dalam rumah tangga menurut undang-undang ini terdiri dari empat macam $^{10}$ yaitu:

1. Kekerasan Fisik adalah perbuatan yang mengakibatkan rasa sakit, jatuh sakit atau luka berat. Dalam konteks relasi personal, bentuk-bentuk kekerasan fisik yang dialami perempuan korban mencakup antara lain tamparan, pemukulan, penjambakan, penginjak-injakan, penendangan, pencekikan, lemparan benda keras, penyiksaan menggunakan benda tajam, seperti pisau, gunting, setrika serta pembakaran. Sedangkan dalam konteks relasi kemasyarakatan, kekerasan fisik terhadap perempuan bisa

\footnotetext{
${ }^{9}$ Anugriaty Indah Asmarany, Bias Gender SebagaiPrediktor Kekerasan Dalam Rumah Tangga, Volume 35, no 1, 1-20, Jurnal Psikologi, 5.

${ }^{10}$ Kementrian Pemberdayaan Perempuan RI, Undang-undang NO.23 Tahun 2004 tentang Penghapusan Kekerasan Dalam Rumah Tangga, 1-5.
} 
berupa penyekapan atau pemerkosaan terhadap pembantu perempuan oleh majikan ataupun pengrusakan alat kelamin (genital mutilation) yang dilakukan atas nama budaya atau kepercayaan tertentu.

2. Kekerasan Psikis adalah perbuatan yang mengakibatkan ketakutan, hilangnya rasa percaya diri, hilangnya kemampuan untuk bertindak, rasa tidak berdaya, dan atau penderitaan psikis berat pada seseorang. Bentuk kekerasan secara psikologis yang dialami perempuan mencakup makian, penghinaan yang berkelanjutan untuk mengecilkan harga diri korban, bentakan dan ancaman yang diberiyang diberi untuk memunculkan rasa takut. Pada umumnya kekerasan psikologis ini terjadi dalam konteks relasi personal.

3. Kekerasan seksual adalah pemaksaan hubungan seksual yang dilakukan terhadap orang yang menetap dalam rumah tangga atau pemaksaan hubungan seksual terhadap salah seorang dalam lingkup rumah tangganya dengan orang lain utnuk tujuan komersial dan atau tujuan tertentu. Kekerasan yang benuansa seksual termasuk sebagai perilaku yang tak diinginkan dan mempunyai makna seksual, atau sering disebut 'pelecehan seksual', maupun berbagai bentuk pemaksaan hubungan seks yang sering disebut sebagai perkosaan.

4. Penelantaran Rumah Tangga yaitu seseorang tidak melaksanakan kewajiban hukumnya tehadap orang dalam lingkup rumah tangga berupa mengabaikan memberikan kewajiban kehidupan, perawatan atau pemeliharaan kepada orang tersebut. Termasuk dalam kategori penelantaraan rumah tangga adalah memberikan batasan atau melarang seseorang untuk bekerja yang layak di dalam atau di luar rumah sehingga korban berada dalam kendali orang tersebut 
Didalam UU PKDRT adalah identifikasi aktor-aktor yang memiliki potensi terlibat dalam kekerasa. Pada pasal 2 UU PKDRT disebutkan bahwa lingkup rumah tangga meliputi (a) suami, istri, dan anak, (b) orang-orang yang memiliki hubungan keluarga sebagaimana dimaksud pada huruf (a) karena hubungan darah, perkawinan, pesusuan, pengasuhan, dan perwalian, yang menetap dalam rumah tangga dan atau (c) orang-orang yang bekerja membantu rumah tangga dan menetap dalam rumah tangga tersebut sehingga dipandang sebagai anggota keluarga. Identifikasi kekerasan terhadap pekerja rumah tangga sebagai kekerasan domestik sempat mengundang kontraversi karena ada yang berpendapat bahwa kasus tersebut hendaknya dilihat dalam kerangka relasi pekerjaan (antara pekerja dengan majikan). Meskipun demikian, UU PKDRT mengisi jurang perlindungan hukum karena sampai saat ini undang-undang perburuhan di Indonesia tidak mencakup pekerja rumah tangga. Sehingga korban kekerasan dalam rumah tangga adalah orang yang mengalami kekerasan dan atau anacaman kekerasan dalam lingkup rumah tangga.

\section{KETIMPANGAN GENDER.}

Dalam kondisi saat ini masih menunjukkan bahwa perbedaan jenis kelamin dapat menimbulkan perbedaan gender (gender differences) dimana kaum perempuan itu tidak rasional, emosional, dan lemah lembut, sedangkan laki-laki memiliki sifat rasional, kuat atau perkasa.11

Gender difference sebenarnya bukan suatu masalah sepanjang tidak menimbulkan gender inequalities (ketidakadilan gender).

11 Riant Nugroho, Gender dan Strategi Pengarus-Utamaannya di Indonesia, (Yogyakarta: Pustaka Pelajar, 2008), 9. 
Namun, yang menjadi masalah adalah ternyata gender differences ini telah menimbulkan berbagai ketidakadilan, baik bagi kaum laki-laki dan utamanya terhadap kaum perempuan. Namun yang menjadi masalah dan perlu dipertanyakan adalah struktur gender inequalities yang ditimbulkan oleh gender role (peran gender) dan gender differences.

Gender inequalities (ketidakadilan gender) merupakan sistem dan struktur dimana kaum laki-laki dan perempuan menjadi korban dari sistem tersebut. Dengan demikian agar dapat memahami perbedaan gender yang menyebabkan ketidakadilan maka dapat dilihat dari berbagai manifestasinya, yaitu:

\section{Marginalisasi}

Timbulnya suatu kemiskinan yang terjadi dalam masyarakat dan Negara merupakan sebagai akibat dari proses marginalisasi yang menimpa kaum laki-laki dan perempuan yang disebabkan oleh berbagai kejadian, Antara lain, penggusuran, bencana alam atau proses eksploitasi. Bentuk marginalisasi yang sering terjadi terhadap kaum perempuan yang disebabkan oleh gender. Meskipun tidak setiap bentuk marginalisasi disebabkan oleh gender inequalities, namun yang menjadi masalah disini ialah yang disebabkan oleh gender differences (perbedaan gender). Gender differences ini bila ditinjau dari sumbernya dapat berasal dari kebijakan pemerintah, keyakinan, tafsir agama, keyakinan tradisi dan kebiasaan atau bahkan asumsi ilmu pengetahuan.

\section{Subordinasi}

Subordinasi timbul sebagai akibat pandangan gender terhadap kaum perempuan. Sikap yang menempatkan perempuan pada posisi yang tidak penting muncul dari adanya anggapan bahwa perempuan tidak bisa tampil memimpin merupakan bentuk dari subordinasi. Dalam rumah tangga misalnya, dalam kondisi 
keuangan rumah tangga yang terbatas, masih sering terdengar adanya prioritas untuk bersekolah bagi laki-laki disbanding perempuan, karena ada anggapan bahwa perempuan tidak perlu sekolah tinggi-tinggi, yang pada akhirnya nanti akan masuk ke dapur juga.

\section{Stereotype}

Pelabelan atau penandaan negative terhadap kelompok atau jenis kelamin tertentu, secara umum dinamakan stereotip. Banyak sekali bentuk stereotip yang terjadi di masyarakat yang umumnya diletakkan kepada kaum perempuan sehingga berakibat menyulitkan, membatasi, memiskinkan, dan merugikan kaum perempuan. Misalnya, adanya anggapan di masyarakat bahwa perempuan bersolek biasanya dilakukan dalam rangka memancing perhatian lawan jenis, sehingga pada kasus kekerasan maupun pelecehan seksual hal ini selalu dikaitkan bahkan perempuan sebagai korban yang disalahkan.

\section{Violence}

Violence (kekerasan) merupakan assault (invasi) atau serangan terhadap fisik maupun integritas mental psikologis seseorang yang dilakukan terhadap jenis kelamin tertentu, umumnya perempuan sebagai akibat dari perbedaan gender. Bentuk dari kekerasan ini seperti pemerkosaan dan pemukulan hingga pada bentuk yang lebih halus lagi, seperti sexual harassment (pelecehan) dan penciptaan ketergantungan. Violence banyak terjadi karena stereotype gender. Gender violence pada dasarnya disebabkan karena ketidaksetaraan kekuatan yang ada dalam masyarakat. Bentuk dan macam kejahatan yang masuk dalam kategori gender violence dapat meliputi, Antara lain:

a. Bentuk pemerkosaan terhadap perempuan, perkosaan dalam perkawinan juga termasuk di dalamnya, jika seseorang 
untuk mendapatkan pelayanan seksual dilakukan secara paksa tanpa kerelaan dari yang bersangkutan.

b. Serangan fisik dan tindakan pemukulan yang terjadi dalam rumah tangga (domestic violence), termasuk penyiksaan terhadap anak-anak.

c. Kekerasan dalam bentuk pemaksaan sterilisasi dalam program keluarga berencana. Dalam rangka memenuhi target mengontrol pertumbuhan penduduk.

\section{Beban Kerja}

Peran gender perempuan dalam anggapan masyarakat luas adalah mengelolah rumah tangga sehingga banyak perempuan yang menanggung beban kerja domestic lebih banyak dan lebih lama disbanding kaum laki-laki. Bahkan, bagi kalangan keluarga miskin, beban yang harus ditanggung oleh perempuan sangat berat apalagi jika si perempuan harus bekerja di luar sehingga harus memikul beban kerja yang ganda. Kaum perempuan, berkaitan dengan anggapan gender, sejak dini telah disosialisasikan untuk menekuni peran gender mereka. Di lain pihak kaum laki-laki tidak diwajibkan secara kultural untuk menekuni berbagai jenis pekerjaan domestic. Kesemuanya ini telah memperkuat pelanggengan secara kultural dan structural beban kerja kaum perempuan.

\section{KONSEP KONSELING FEMINIS}

Konseling dengan pendekatan feminis merupakan revolusi konseling dan sebagai pendekatan baru dalam kurun waktu tiga decade terakhir. Konseling feminis sering disebut sebagai feminist counseling, counseling for women, sedangkan dalam dimensi klinis sering deisebut sebagai feminist counseling and therapy atau feminist 
counseling and psychotherapies. Konseling feminis dalam mas perkembanganya dilandasi dengan berbagai kajian tentang isu kesehatan mental pada perempuan, dilengkapi dengan pentingnya pemahaman secara khusus tentang perempuan dibidang layanan konseling dan psikoterapi. Konsep konseling feminis tidak terlepas dari pemikiran tentang community counseling. Model konseling berbasis komunitas menjadi salah satu strategi dalam konseling bagi perempuan korban KDRT. Model ini menekankan pada orientasi, fokus intervensi dan keterampilan khusus yang diperlukan.

Dalam konseling feminis ada dua hal pokok yang harus diperhatikan yaitu pertama, memperkaya kajian secara rasional pada bidang yang berkaitan dengan jenis kelamin (sex), gender, feminism, psikologi perempuan, keragaman budaya, emporwermet. Kedua, mengeksplorasi keunggulan secara psikologis terhadap hubungan yang egaliter antara konselor dengan konseli. Pendekatan feminis berusaha mengeliminasi ketidakadilan dalam prosedur penilaian secara psikologis agamenjadikan pihak perempuan menjadi lebih baik. ${ }^{12}$ Konseling feminis merupakan refleksi dari berbagai bidang secara alamiah (nature). Konseling feminis merupakan kombinasi yang unik antara konselor yang memiliki orientasi gender dengan pendekatan konseling. ${ }^{13}$

Secara faktual kekerasan terhadap perempuan menunjukkan bukti-bukti yang merefleksikan ketimpangan kekuatan sosial budaya antara laki-laki dengan perempuan. Bagaimanapun juga harus disadari dan dipahami bahwa kekerasan terhadap perempuan dan relasi personal merupakan tindakan kriminal yang memberikan peluang bagi korban untuk menuntut pelaku pengadilan. Perempuan

12 Barbara Brown, Foundations Of Feminist Theraphy, 2006. Dalam http://media.wiley.com/product_data/excerpt/69/0471374369.pdf, 1-2

${ }^{13}$ Enns, Carolyn Zerbe, Feminist Theories and Feminist Psychotherapies: Origins, Themes, and Diversity, (New York: The Hawworth Press Inc 2004), 19 
merupakan pihak paling rentan terhadap kekerasan dalam rumah tangga maupun dalam relasi personal. Derajat keseriusan masalah kekerasan menunjukkan peningkatan sepanjang waktu, sehingga bukan tidak mungkin menimbulkan kerusakan permanen pada korban. Dampak psikologis korban adalah dapat menampilkan tingkah laku merusak diri (self-destructive behavior). Satu hal yang mesti diingat adalah bahwa kekerasan terhadap istri atau pasangan bukan merupakan fenomena baru tetapi merupakan fenomena yang telah berlangsung lama. ${ }^{14}$

Kekerasan biasanya dilakukan oleh anggota keluarga yang memiliki kekuatan dan kekuasaan baik secara fisik, psikis maupun secara ekonomi sehingga memunculkan perilaku mengintimidasi, meremehkan, dan bentuk-bentuk kekerasan fisik seperti pemukulan dan penganiyaan. Deborah Sinclair menyebutkan bahwa hal-hal yang mendasari semua bentuk kekerasan adalah ketidakseimbangan kekuasaan dan kekuatan antara pelaku kekerasan dan korbanya.

Batasan kekerasan terhadap perempuan dalam rumah tangga yaitu kekerasan terhadap perempuan dalam hubungan intim mencakup usaha usaha dari pasangan untuk mengintimidasi, baik dengan ancaman atau melalui penggunaan kekuatan fisik untuk menyerang tubuh perempuan atau barang-barang miliknya. Tujuan dari serangan tersebut adalah mengendalikan tingkah laku perempuan atau memunculkan rasa takut. Bentuk-bentuk kekerasan dalam rumah tangga (KDRT) meliputi kekerasan fisik, kekerasan seksual, kekerasan psikologis dan kekerasan berdimensi ekonomi. ${ }^{15}$

Prinsip kesetaraan antara konselor dengan konseli ditandai dengan kemampuan konselor untuk memandang konseli sesuai dengan potensinya, menginformasikan kepada konseli tentang proses

\footnotetext{
${ }^{14}$ Deborah Sinclair, Memberdayakan Perempuan Korban Kekerasan Dalam Rumah Tangga/Hubungan Intim (Terjemahan: Betariani \& Kristi Poewandari, 1999) 25

${ }^{15}$ Ibid, 26
} 
konseling dan perananya secara tepat, memakai berbagai strategi dan mengedepankan kemampuan dan kemandirian konseli, mendorong untuk mengekspresikan kemarahan, menjadi model perilaku yang baik bagi konseli. ${ }^{16}$

Model konseling berbasis komunitas menjadi salah satu strategi dalam konseling bagi perempuan korban KDRT. Marecek dan Hare-Mustin mendeskripsikan tiga prinsip konseling gender (orientation feminist to therapy) yaitu:

a. Pendekatan untuk memunculkan kesadaran gender, konseli belajar membedakan Antara problem perilaku dalam dirinya dengan konstruksi sosial yang terbangun dalam masyarakat. Pendekatan ini sama dengan pendapat Gilbert, the personal is political.

b. Womwn-validating process, konseli belajar menilai pengalamanpengalamannya dan mengenali kekuatan-kekuatan pada dirinya.

c. Hubungan secara egaliter Antara konseli dengan konselor ditujukan untuk mendorong keprcayaan dirinya, dan berperan aktif dalam proses konseling.

Tujuan dari pendekatan konseling feminis ialah untuk melakukan intervensi secara personal, keluarga dan komunitas yang mempengaruhi faktor kesehatan mental mereka (perempuan) yang disebabkan oleh intrapersonal, hubungan interpersonal, maupun lembaga. Tujuan jangka panjangnya ialah membangun kekuatan personal-sosial dan resiliensi terhadap strategi menghadapi trauma

${ }^{16}$ Jill Elaine Rader, The Egalitarian Relationship in Feminist Theraphy. Dissertation The University of Texas at Austin 2003. Dalam: http://dspace.lib.utexas.edu/bitstream/2152/779/1/raderje039.pdf. 46 
dan stress pada masa lalu, sekarang, maupun masa yang akan datang. ${ }^{17}$

Terdapat 4 (empat) isu yang melandasi konseling feminis, yaitu pertama, setiap orang memiliki kapasitas yang sama dalam menentukan pilihan hidupnya. Kedua, konselor sebagai salah satu orang yang berperan dalam membantu membuat pilihan hidupnyaharus mampu menjadi teladan bagi konseli. Ketiga, ada keyakinan nilai yang didasarkan pada standar-standar etis pada saat proses konseling maupun alternativ pilihan yang dibuat. Keempat, memerlukan keterlibatan pihak eksternal (masyarakat) untuk membangun konstuksi gender. ${ }^{18}$ Agar konselor dapat memberikan intervensi yang efektif maka sebelum memberikan pendampingan kepada perempuan korban kekerasan harus didahului pemahaman terhadap nilai-nilai dan keyakinan tentang hal-hal berikut ini: ${ }^{19}$

1. Tidak dibenarkan tindakan kekerasan kepada perempuan dengan berbagai alas an apapun.

2. Perempuan pada dasarnya tidak masokhis (suka disakiti, mendapatkan kenikmatan dari disakiti).

3. Faktor utama yang menyebabkan perempuan tetap mempertahankan hubungan dengan pasanganya adalah peran tradisional perempuan yang diperoleh dari pranata sosial dalam masyarakat.

4. Fokus pembicaraan awal pada sesi konseling adalah kekerasan yang terjadi bukan pada masalah-masalah inti dalam perkawinan.

${ }^{17}$ Barbara Brown, Foundations Of Feminist Theraphy, 2006. Dalam http://media.wiley.com/product_data/excerpt/69/0471374369.pdf. 23

${ }^{18}$ Ibid, 25

19 Deborah Sinclair, Memberdayakan Perempuan Korban Kekerasan Dalam Rumah Tangga/Hubungan Intim (Terjemahan: Betariani \& Kristi Poewandari, 1999) 28 
5. Siapapun yang menangani kasus perempuan korban kekerasan harus dapat menjadi model kompoten, sukses dan asertif.

Ada beberapa catatan tentang proses konseling bagi perempuan korban kekerasan, yaitu sebagai berikut ini:

1. Memasukkan berbagai isu, masalah dan konteks sosio-kultural korban.

2. Memberikan perhatian secara proporsional terhadap pengalaman simtomatis.

3. Memakai pendekatan multimodal, contohnya tidak hanya menggunakan pendekatan kognitif-behavior tetapi juga intervensi dan advokasi kepada lingkungan sosial korban.

Teknik-teknik dalam konseling feminis dikembangkan dari beberapa pendekatan tradisional dan diadaptasi menjadi model konseling femnis. Ada bebarapa teknik dan strategi konseling feminis yang dikembangkan adalah sebagai berikut: ${ }^{20}$

1. Pemberdayaan. Kekuatan konseling feminis adalah memberdayakan konseli. Konselor membantu konseli agar dapat menjadi pribadi yang mandiri dan mempunyai partisipasi yang seimbang dalam masyarakat.

2. Keterbukaan. Hubungan Antara konselor dengan konseli dibangun melalui keterbukaan tidak hanya sharing informasi dan pengalaman tetapi ada hubungan timbal balik Antara konselor dengan konseli.

3. Menganalisis peran gender. Konselor mengeksplorasi harapanharapan konseli yang berkaitan dengan peran gender dan dampaknya pada pengambilan keputusan untuk masa yang akan datang.

20 Gerald Corey, Teori dan Praktik Konseling dan Psikoterapi (Bandung:PT Refika Aditama 2005) 26 
4. Intervensi peran gender. Konselor memberikan pemahaman yang menekankan pada perbedaan peran Antara laki-laki dengan perempuan.

5. Bibliotherapy. Konselor memakai sumber-sumber seperti buku non fiksi, buku teks bimbingan \& konseling, autobiografi, video pendidikan \& pengetahuan sebagai bahan diskusi bersama konseli.

6. Latihan untuk asertif. Konselor membantu konseli untuk bersikap asertif sehingga konseli mempunyai kesadaran tentang hak-haknya. Membantu mengubah stereotype negative peran gender, mengubah keyakinan yang negtaif dan mengimplementasikan perubahannya dalam kehidupan.

7. Reframing dan relabeling. Konselor membantu konseli untuk memahami akar permasalahan karena problem yang dialami konseli berhubungan dengan tekanan sosial (social pressure) bukan semata-mata berasal dari dirinya.

8. Group work. Pada akhir sesi konseling individual, konselor memberikan kesempatan konseli untuk bergabung dalam kelompok. Langkah ini dimaksudkan agar konseli merasa tidak sendiri dan dapat mendiskusikan pengalaman hidupnya.

9. Social action. Konselor mendorong konseli untuk terlibat dalam kegiatan pemberdayaan perempuan, menuliskan pengalaman hidupnya atau aktif dalam komunitas pendidikan yang berlatar isu gender.

Riset Toni Sands dilatar belakangi oleh pengalaman depresi yang dialami oleh perempuan sehingga pendekatan konseling feminis yang dikembangkan dikhususkan bagi perempuan yang mengalami 
depresi. Pokok-pokok dalam feminist counseling adalah sebagai berikut $:^{21}$

1. Hubungan yang setara (Eligatarian Relationship)

Egalitarian relationship, merupakan bentuk hubungan antara konselor dengan konseli. Konseling dipandang sebagai proses kerjasama, dimana setiap individu dihargai dalam kapasitas kekuatan yang sama untuk mendiskusikan pokok masalah dan strategi pemecahan masalahnya. Ditambahkan lagi bahwa walaupun metode kerjasama ini tidak mungkin untuk dilakukan pada setiap konseli tetapi proses ini harus tetap dilaksanakan sebagai salah satu tahap dalam konseling feminis. Egalitarian relationship menggunakan pendekatan daar humanist yaitu mendengar secara empatik, dorongan tak bersyarat (unconditional support), mutual respect, membantu membuka ketertutupan konseli secara tepat. Konselor diharapkan membantu memahami secara rasional terhadap permasalahan yang dihadapi dan membebaskan dari prasangka.

2. Personal memiliki posisi politis dalam masyarakat (The Personalis Political)

The personal is political sering diasumsikan, dihubungkan dan dipengaruhi oleh iklim sosial politik dalam kehidupan seseorang. Perspektif konseling feminis tidak dapat dilepaskan dari masalah sosial, politik, ekonomi dan faktor institusional yang mempengaruhi pilihan-pilihan individu dalam mengambil keputusan. Dalam konteks ini konselor diarahkan untuk memakai pilihan istilah proses memecahkan masalah kehidupan atrau strategi memecahkan masalah dari pada memakai istilah

${ }^{21}$ Toni Sands, Feminist Counseling and Female Adolescents: Treatment Strategies for Depression. Jurnal of Mental Health Counseling Vol 20 Januai 1998. 42-45 
penyakit sosial (pathologi sosial). ${ }^{22}$ Prinsip kedudukan personal secara politis adalah menguatkan keyakinan perempuan korban tentang dampak psikologis sebagai akibat dari lingkungan yang negatif (seperti bias jenis kelamin, menekankan perbedaan status, dan mono-kultural). Kemampuan membangun keyakinan akan berimplikasi pada perubahan secara mendasar berkaitan dengan kehidupan pribadi dan lingkungan sosialnya. Konselor diharapkan memiliki kesadaran masalah moral, sosial dan politik uang merupakan akar permasalahan dari terjadinya kekerasan dalam rumah tangga (terutama kekerasan terhadap istri). Pemahaman secara mendalam tentang problematika KDRT oleh Konselor, terbentuk dari kesadaran tentang masalah sosial,

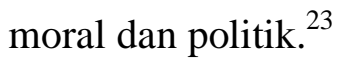

Konseli mengarahkan konseli membangun pemahaman personal bahwa tdak ada kekuatan yang dapat mengintimidasi, meneror, mengeksploitasi mereka (perempuan) konselor berusaha untuk tidak menyalahkan konseli secara pathologis. Kekuatan konseling feminis adalah konseli diarahkan untuk membuat perubahan yang lebih baik pada diri dan lingkunganya. ${ }^{24}$

3. Konsep Nilai Berspektif Perempuan (Valuing the Female Perspektive)

Konselor dituntut untuk memiliki perspekif nilai dari sudut pandang konseli, karena merupakan representasi dari keyakinan konselor bahwa mereka harus mempelajari karakteristik perempuan dalam membangun pandangan tentang dunia perempuan (female-centered views). Sturdivant mengajukan

${ }^{22}$ Enns, Carolyn Zerbe, Feminist Theories and Feminist Psychotherapies: Origins, Themes, and Diversity, (New York: The Hawworth Press Inc 2004), 11

${ }^{23}$ Toni Sands, Feminist Counseling and Fe,ale Adolescents: Treatment Strategies for Depression. Jurnal of Mental Health Counseling Vol 20 Januai 1998. 48

${ }^{24}$ Ibid, 51 
beberapa sikap konselor yang menunjukkan kemampuan memahami dalam perspektif perempuan korban seperti, empati, kejasama, instituisi, interdependensi dan menekankan aspek hubungan yang seimbang. Valuing the female perspective, sebagai upaya konselor untuk memahami dan memfasilitasi konseli dalam mengekspresikan perasaanya sesuai dengan nilai yang diyakininya.

\section{KESIMPULAN}

Bahwa yang menjadi penyebab tindak kekerasan dalam rumah tangga yaitu masih adanya anggapan bahwa posisi suami jauh lebih tinggi daripada istri, ini karena pemahaman yang keliru terhadap bias gender. Selain itu faktor lain yang menjadi penyebab terjadinya kekerasan dalam rumah tangga ialaha konflik dalam pernikahan, rendahnya status sosial ekonomi, kemiskinan, mobilitas penduduk tinggi dan perubahan lingkungan sosial yang cepat.

Akibat yang ditimbulkan dari tindak kekerasan dalam kasus KDRT adalah dari segi fisik perempuan korban KDRT akan mengalami kondisi tubuh yang memar akibat pukulan dan penyiksaan. Dai segi psikis perempuan korban KDRT akan mengalami depresi yang mengakibatkan ketakutan, hilangnya rasa percaya diri, hilangnya kemampuan untuk bertindak dan rasa tidak berdaya, meningkatkan rasa ketergantungan pada suami meskipun sering disiksa dan memicu rasa dendam.

Dalam Konseling Feminis konselor menggunakan distorsi kognitif tanpa memahami konteks sosial budaya di mana masalah itu muncul. Untuk mmelakukan intervensi konseling kepada perempuan yang mengalami depresi diperlukan tiga prinsip dasar yaitu kesetaraan, kebijakan personal dan female perspective. Strategi 
melakukan intervensi konseling kepada perempuan korban KDRT diperlukan tiga prinsip dasar yaitu kesetaraan, kebijakan personal dan female perspective. Pendekatannya yang berorientasi feminis mendeskripsikan bahwa untuk membantu mengurangi depresi pada perempuan diupayakan membangun kesadaran peran gender dimulai dari perbedaan secara biologis yang akhirnya berimplikasi pada peran sosial gender. Membangun kesadaran akan berpengaruh kuat dengan stereotype gender dalam masyarakat sehingga untuk mengefektifkan konseling ditempuh dengan strategi yang humanis dan berperspektif perempuan.

\section{DAFTAR PUSTAKA}

Asmarany Indah Anugriaty, Bias Gender SebagaiPrediktor Kekerasan Dalam Rumah Tangga, Volume 35, no 1, 1-20, Jurnal Psikologi, hlm 5.

Brown, Barbara. (2006). Foundations of Feminist Therapy. [Online]. Tersedia:http//media.wiley.com/product_data/excerpt/69/04713 743/0471374369.pdf.

Corey Gerald, Teori dan Praktik Konseling dan Psikoterapi Bandung: PT Refika Aditama 2005

Enns, Carolyn Zerbe. (2004). Feminist Theories and Feminist Psychotherapies : Origins, Themes, and Diversity. Second Edition. [Online]. New York : The Haworth Press, Inc. Tersedia http://www.haworthpress.com.innopac.lib.bcit.ca /store/ SampleText/5092.pdf.

Kementrian Pemberdayaan Perempuan RI, Undang-undang NO.23 Tahun 2004 tentang Penghapusan Kekerasan Dalam Rumah Tangga. 
Komisi Nasional Perlindungan Perempuan. Catahu Komisi Nasional Hak Asasi Manusia. Jakarta:Komnas Perempuan

Ni Luh Arjan, Kesetaraan dan Keadilan Gender (KKG) dan Tantangan Global, Vol. 1, No. 2 Agustus 2008, Jurnal Ekonomi dan Sosial

Nurhayati Eki, "Domestik Violence", Jurnal, EQUALITA STAIN Cirebon, Vol No 2 Juni, 2003. Hal 47-48

Nugroho Riant, Gender dan Strategi Pengarus-Utamaannya di Indonesia, Yogyakarta: Pustaka Pelajar, 2011.

Pancasilawati Abnan, Kekerasan Dalam Rumah Tangga Perspektif UU NO.23 Tahun 2004 tentang PKDRT dan Hukum Islam, Vol 3 No 2 Juni 2003, Jurnal Equalita Stain Cirebon, hlm 1

Pusat Pembinaan dan Pengembangan Bahasa Indonesia, Kamus Besar Bahasa Indonesia, Jakarta: Balai Pustaka, 1994.

Rader, Jill Elaine. (2003). The Egalitarian Relationship in Feminist Therapy. Dissertation. The University of Texas at Austin [Online]. Tersedia :

http ://dspace.lib.utexas.edu/bitstream/2152/779/1/raderje 039.pdf

Sararwati Rika, Perempuan dan Penyelesaian Kekerasan dalam Rumah Tangga,Bandung: PT. Citra Aditya Bakti, 2006.

Sands, Toni., (1998). Feminist Counseling an Female Adolescents : Treatment Strategies for Depression. Dalam Journal of Mental Health Counseling [Online]. Vol. Jan 1998. (20,1). 42-45. ProQuest Education Journals. Tersedia :http://proquest/pqdweb.

Sinclair, Deborah. (1999). Memberdayakan Perempuan Korban Kekerasan Dalam Rumah Tangga/Hubungan Intim. (Terjemahan : Betariani \& Kristi Poerwandari). Program kajian wanita PPs. Universitas Indonesia. 